\title{
Recognizing and Applying Some Important Standards of Sme-S in the Republic of Macedonia
}

\author{
Ilaz Ameti ${ }^{1}$, Naser Ahmeti ${ }^{2}$ \\ ${ }^{1}$ Faculty for Business Administration, University of Tetovo, Skopje, Republic of Macedonia \\ ${ }^{2}$ Sekretariatfor Implementation Ohrid Agreement, Skopje, Republic of Macedonia
}

Email address:

ilaz.ameti@hotmail.com (I. Ameti)

To cite this article:

Ilaz Ameti, Naser Ahmeti. Recognizing and Applying Some Important Standards of Sme-S in the Republic of Macedonia. International Journal of Science, Technology and Society. Vol. 5, No. 6, 2017, pp. 182-185. doi: 10.11648/j.jjsts.20170506.12

Received: August 31, 2017; Accepted: September 19, 2017; Published: October 13, 2017

\begin{abstract}
For the highest amount of companies, today the quality issue presents an important first hand problem related specifically with goods and services that companies provide to consumers. Application of quality systems is not complete yet, but the goal is to have competition between companies until achieving completed managing Total Quality Management. For the highest amount of Small and medium-sized enterprises nowadays, the quality issue presents an important first hand problem related specifically with goods and services that companies provide to consumers. Therefore, can say that the main characteristic of products and services is the term. With this project to contribute more for better recognition of ISO-standards International Organization for Standardization and HACCP-system, Hazard Analysis and Critical Control Point their impact on the effectiveness, profitability and fulfilling the needs of customers in the market.
\end{abstract}

Keywords: ISO Standards, Competition, HACCP System, Total Quality Management

\section{Introduction}

For the highest amount of Small and medium-sized enterprises nowadays, the quality issue presents an important first hand problem related specifically with goods and services that companies provide to consumers. Therefore, can say that the main characteristic of products and services is the term quality.

This term obviously its hard to have the same value in different environments by consumers, so the quality is defined in different ways by different authors.

There are a lot of definitions about quality but one of the most important its from JURAN (1999) which it says that with quality are determined product characteristics which complement requests and shortages of consumers.

Companies which are oriented to produce quality products, not only will complement requests and needs of consumers, they will also exceed them.

According to Kuei et al (2001) they claim that the good quality of products leads the company to save existed consumers and also attracting new consumers which will directly affect on consumer growth.
While according to Shuklev (2004) the quality is defined as one degree of perfection, in most cases its defined as ability to complement consumer requirements.

According to authors V. Çepjunovski, Gj. Çepjunovski (1993) there are several factors which define the quality as their function, they are:

(Man), (Material), (Machine), (Function), (Method), (Measurement), (Management), (Motivation), (Market), (Money).

The term quality is multidisciplinary category, which can not be treated with just one definition. But, last time as the most desirable definition is ISO-standards 8402/1986 (Quality Vocabulary) where quality is defined as Collection of all virtues and characteristics of good sun and services for complementing consumer needs ${ }^{1}$. Standards represents a universal business language and helps achieving an accurate and complete understanding in the field of technology, economy ans social development. According to V. Çepjunovski, Gj. Çepjunovski (1993). The main purposes of ISO-standards in production are:

1 Ţivković, Tivan Upravljanje kvalitetom, Poslovna škola, Megatrend, Beograd, 1999 
-Rational use of raw materials

-Organizations of production

-Productivity growth

-Costs reduction

-Efficient collaboration with the international economy etc.

While the system HACCP- is to identify potential problems of food security and to determine during the control or prevent them.

HACCP-it's a system which identifies, estimates and controls the risks that are important for food security ${ }^{2}$.

Today, almost all of companies Small and medium-sized enterprises in Macedonia try to apply total quality management with purpose to offer products and services with the best quality for consumers in market.

\section{Method}

This study brings newness about this problematic and at the same time we tried to explain importance of standard application in Business Organizations as a growing and defiant purpose of quality during production, imaging improvement to the firm, fulfilling the needs of consumers, exploiting different literature above standards and also other basic date of Statistical entity, Agriculture Ministry and Ministry of Economy.

\section{Results from Research}

The quality is needed during all the production cycle process in the company, from insurance of raw materials, during transformation in the finished product. This actually means that is held accountable for quality of all employees in the company from the highest level manager to the last worker in production.

When it comes to increasing the quality we suppose the production in the food industry ex. (the dairy industry and milk products) then have to be based in some principles that the total quality is associated:

-Fair economy with working ground (plant rotation)

-Better selection of plant varieties

-Selection of the newest sharing animals

-Application of the new technology in production and processing

-Renovation of the material-technic base ${ }^{3}$.

So the whole concept Total Quality Management and the strategy for growth quality by the companies for milk processing we can explain it through the spiral which explains standard procedures for operating in the enterprise.

The quality spiral is surrounded by factors which affect the quality, companies are obliged to apply for competing in the market.

The chain concept for high quality and in its context for dairy industry its based from market research, recent

2 http://www.mti-ks.org/repository/docs/Doracak i sistemeve të përzgjedhura menaxheriale sipas standardeve ndërkombëtare

3 M. Pe \{evski: Upravuvaëe so kvalitetot vo agrokompleksot, Zdru`enie na Agroekonomisti na R. Makedonija\}, Skopje, 2003, str. 315 development of quality specification, supply, preparation and control during the process, packing and until the sale or up to the consumer.

All the Macedonian companies in the dairy industry are obliged to apply ISO-9000 standards (9001-9004) and also the HACCP system (Hazard Analysis and Critical Control Point) which is based on these fundamental principles:

-Determination of risk analysis

-Determination of critical control points

-Determination of critical points, preventive during identification

-Authenticity and implementation of effective procedures during control and monitoring

-Definition and correction of the masses which are necessary to apply during surveillance when its found that critical point its exceeded

-Creating a procedure for verification and functioning of the HACCP system

-Creating a procedure for documentation and retention of notes with the help of HACCP system.

\section{Discussion}

Since 1987 to Small and medium-sized enterprises have started more and more with the application of ISO-9000 standards. Their certification as first started in some places of Western Europe, which it says that until the year 2000 the number was around 220.127 while the number of companies with ISO-standards in the Balkan looks like following: (Table 1.)

Table 1. Certification of companies with ISO 9000 standards in some places of Balkan.

\begin{tabular}{llllll}
\hline & Albania & Macedonia & Bulgaria & Montenegro & Serbia \\
\hline 2010 & 52 & 333 & 6248 & 85 & 1790 \\
2011 & 164 & 290 & 5001 & 146 & 3228 \\
2012 & 149 & 396 & 6037 & 102 & 2750 \\
2013 & 167 & 399 & 5378 & 118 & 2366 \\
2014 & 171 & 446 & 5730 & 130 & 2637 \\
\hline
\end{tabular}

From this table verify that Bulgary is the country with one step ahead in company certification with ISO standard, then Serbia but in the other countries the number is smaller.

\section{Conclusions}

For the highest amount of Small and medium-sized enterprises nowadays, the quality issue presents an important first hand problem related specifically with goods and services that companies provide to consumers. Therefore, we can say that the main characteristic of products and services is the term quality.

This term obviously its hard to have the same value in different environments by consumers, so the quality is defined in different ways by different authors.

The term quality is multidisciplinary category, which can not be treated with just one definition. But, last time as the most desirable definition is ISO-standards 8402/1986 
(Quality Vocabulary) where quality is defined as Collection of all virtues and characteristics of good sun and services for complementing consumer needs. Standards represents a universal business language and helps achieving an accurate and complete understanding in the field of technology, economy and social development.

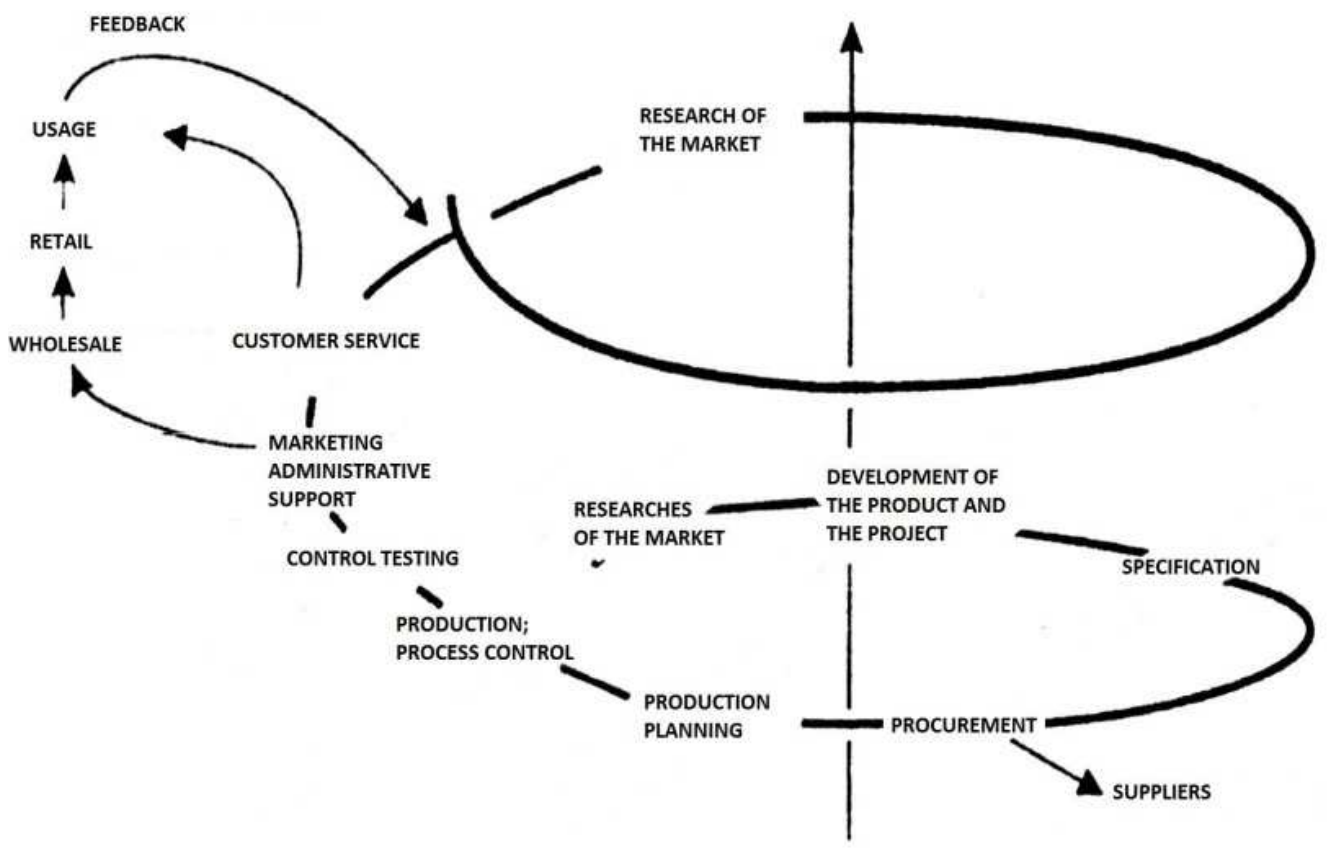

Source: V. Cepujnoska, Gj. Cepujnovski, 1993, “Osnovi na upravuvanjeo so kvalitetot: fillozofija, metodollogija, iskustva”, Skopje, f. 158.

Figure 1. Spiral for achieving the quality in enterprise.

\section{Recommendations}

a. For the highest amount of companies, today the quality issue presents an important first hand problem related specifically with goods and services that companies provide to consumers.

b. Factors which define the quality as their function are: (Man), (Material), (Machine), (Function), (Method), (Measurement), (Management), (Motivation), (Market), (Money).

c. Standards represents a universal business language and helps achieving an accurate and complete understanding in the field of technology, economy and social development.

d. Today when the competition is fierce in the world market, the dermal part of companies should have certification with ISO standards.

e. ISO standards are a set of international standards for quality management and assurance that have been accepted in many countries around the world.

f. The purpose of ISO standards is to provide consumers with quality products and services.

g. All the Macedonian companies in the dairy industry are obliged to apply ISO-9000 standards (9001-9004) and also the HACCP system (Hazard Analysis and Critical Control Point) which is based on some fundamental principles.

h. Application of Total Quality Management shows a positive effect on enterprise results, especially today when TQM techniques apply almost all enterprises in order to withstand competition in the global market.

i. Enterprise certification on these standards reports on improved services, increased awareness of enterprise quality, and focus on every customer requirements.

\section{References}

[1] Ameti. I (2013): Organization of the market for agricultural products in the Balkan region. Doctoral dissertation, Ss, Faculty of Agricultural Sciences and Food, Skopje.

[2] Kapaj. I (2016) Ndikimi i standardeve ISO 9001 në efektivitetin e ndërmarrjeve të vogla dhe të mesme në rajonin e pollogut (Republika e Maqedonisë).

[3] Peshevski M., Zivkovic D., Milovancevic Z., Petkov R. (2014): The production and market of macedonian ajvar. AAEM 9th International Conference: The Role of Agricultural Economic Sciences in Agriculture and Rural Development in the Balkan Countries, 24-25 April 2014, Ohrid, Macedonia.

[4] V. Cepujnoska, Gj. Cepujnovski, (1993) Osnovi na upravuvanjeo so kvalitetot: fillozofija, metodollogija, iskustva, Skopje.

[5] Venetike Nakuçi, Ariana Çepani, Suzana Panariti, Ira Gjika "Menaxhimi i operacioneve" Tiranë, 2002 Violeta.

[6] Ţivković, Țivan Upravljanje kvalitetom, Poslovna škola, Megatrend, Beograd, 1999.

[7] Taylor, W. Andrew. "Senior executives and ISO 9000: attitudes, behaviours and commitment." International Journal of Quality \& Reliability Management 12, no. 4 (1995). 
[8] Samat, Nusrah, T. Ramayah, and Yusliza Mohd Yusoff. "Do ISO certified SME's have higher quality practices? Empirical insights from the Northern region of Malaysia." International Journal of Business and Management 3, no. 3 (2009).

[9] Weston Jr, F. C. "What do managers really think of the ISO 9000 registration process?" Quality progress 28, no. 10 (1995).

[10] Rexhepi. G. Menaxhimi i cilësië totale, Shkup 2010.

[11] Kotler Ph. K. L. Keller (2006), Marketing management, 12-th ed, N Jersey.
[12] Шуклев Бобек:, Менаџмент на малиот бизнис, 6-то издание, Економски факултет-Скопје, Скопје, 2015.

[13] Шуклев Бобек:, Менаџмент на малиот бизнис, Економски факултет-Скопје, Скопје, 2000 f.23.

[14] Wruck, Karen Hopper, and Michael C. Jensen. "Science, specific knowledge, and total quality management." Journal of Accounting and economics 18, no. 3 (1994).

[15] http://www.mti-ks.org/repository/docs/Doracak i sistemeve të përzgjedhura menaxheriale sipas standardeve ndërkombëtare. 